AMERICAN JOURNAL OF SCIENTIFIC AND INDUSTRIAL RESEARCH

(C) 2012, Science Hu $\beta$, http://www.scihub.org/AJSIR

ISSN: 2153-649X, doi:10.5251/ajsir.2012.3.5.252.262

\title{
Near-surface structural model for enhanced seismic data acquisition and processing in North-Central Niger Delta
}

\author{
G. I. Alaminiokuma and J. Amonieah
}

Department of Physics, Rivers State University of Science and Technology, Nigeria

\begin{abstract}
Near-surface structural model was geostatistically developed from a sample density of 36 Uphole/LVL survey points to determine the properties of the weathering layer geological materials. Results from the generated Isopachs and Isovels show a dominant 2-weathered layer model with 1-weathered layer model in only five locations, mainly along the escarpment. The average thickness of the weathering layer to the first refractor consolidated layer is $18.84 \mathrm{~m}$ with an average velocity of $1791.40 \mathrm{~ms}^{-1}$. Weathering thicknesses ranged from 1.3 to $4.7 \mathrm{~m}$, subweathering thicknesses from 11.4 to $35.7 \mathrm{~m}$; weathering velocities from 119 to $941 \mathrm{~ms}^{-1}$; subweathering velocities from 425 to $1665 \mathrm{~ms}^{-1}$ and consolidated layer velocities from 1610 to 2208 $\mathrm{ms}^{-1}$. Proper application of these results will prove very useful and reliable for the enhancement of optimization processes during stages of seismic data processing and serve as baseline data for future 4D seismic data acquisition for accurate mapping of the deep underlying structures for oil and gas exploration in the North-Central part of the Niger Delta.
\end{abstract}

Keywords: Near-surface, Geostatistics, Isopachs, Isovels and Niger Delta

\section{INTRODUCTION}

Optimization processes during stages of seismic data acquisition and processing can be enhanced by applying good near-surface structural models to bypass the erratic characteristics and minimize the effects of the weathering layer. The near-surface weathering zone is usually aerated, loose, unconsolidated with abnormally low velocities, and variable thicknesses, densities and lithologies. These properties cause high absorption of seismic energy resulting to poor records from shots, time delays to rays thus shifting reflection events out of their true relationships, large velocity contrast sharply bending seismic rays into near-vertical travel path, high impedance contrast making it an excellent reflector of multiples, high amplitude of reflection resulting in false indications of significant structural relief features among others.

Uphole and shallow refraction surveys are the most important and widely used methods for studying the near-surface characteristics (Dobrin, 1983). The Uphole method provides the most direct measure of the near-surface characteristics (Telford, et al, 1976). Information about the near-surface velocities, depths and thicknesses of the layers in the vertical direction can be delineated by this method. It also provides lithological information of the near-subsurface at the point of drilling through formation. The first-break amplitudes are also studied to identify the high velocity medium. The Uphole survey, when conducted at close intervals in a stable area, delineate the proper depth for the energy source to be placed. The energy generated at such depth is good in terms of frequency contents, capable of travelling to sufficiently longer distances minimizing the problem of ground rolls (Singh and Kumar, 2006). Uphole survey provides additional information to detect velocity inversions and recognize thin and hidden beds, which refraction statics fail to resolve (Marsden, 1993). Shallow Low Velocity Layer (LVL) refraction surveys give the velocity information of the subsurface in the lateral direction and their processing can depict parameters like depth of different near-surface layers and velocities within those layers (Singh and Kumar, 2006).

Several researches on this near-surface zone had been conducted in the Niger Delta, Nigeria. Uko, et al. (1992) determined the weathering structure of the Eastern-Central Niger Delta employing 168 LVL refraction survey data. Results show that the LVL thickness in this region is highly variable ranging between 2.9 and $45.5 \mathrm{~m}$ with a regional average of about $20.0 \mathrm{~m}$. The weathered layer and the refractor beneath it have average compressional wave velocities of about 500 and $1732.0 \mathrm{~ms}^{-1}$ respectively. Eze, et al. (2003) determined the LVL characteristics 
of the mangrove swamp, South-Central Niger Delta using data from 14 Upholes only. Results show a variation in thickness of the LVL from 2.0 to $5.7 \mathrm{~m}$ with an average of $3.4 \mathrm{~m}$. The velocity of the LVL ranges between 295 and $727 \mathrm{~ms}^{-1}$ with an average of $562.7 \mathrm{~ms}^{-1}$ while the velocity of the sub-weathered layer ranges between 1502 and $1918 \mathrm{~ms}^{-1}$ with an average of $1716 \mathrm{~ms}^{-1}$. Enikanselu P.A. (2008) analyzed the weathering layer characteristics of the North-Western Niger Delta with 29 LVL refraction lines and one Uphole shotpoint. The results reveal an average regional thickness of $4.4 \mathrm{~m}$. The average weathered layer compressional wave velocity was about $525 \mathrm{~ms}^{-1}$. The underlying consolidated layer has an average velocity of about $1800 \mathrm{~ms}^{-1}$. Osagie (2009) determined the weathering structure of the South-Western Niger Delta using seismic refraction data only from 50 locations. The thickness of the low velocity layer in the area varies from 3.6 to $46.2 \mathrm{~m}$ with a regional average of about $24.0 \mathrm{~m}$. The weathered layer and the refractor beneath it were found to have average $\mathrm{P}$-wave velocities of about 600.0 and $1842.0 \mathrm{~ms}^{-1}$ respectively.

Considering the advantages provided by using the Uphole or shallow refraction survey, a geostatistical integration of densely sampled Uphole and LVL surveys in a single analysis to achieve a better model of the near-surface is highlighted in this work.

\section{Location and Geology of the Study Area:}

The study area encompasses the North-Central part of the Niger Delta (Figure 1.0) and covers about 468.5 and $313.16 \mathrm{~km}^{2}$ of surface and subsurface area respectively. It is delimited by Latitude $05^{\circ} 00^{\prime \prime} 0^{\prime}$ and $05^{\circ} 30^{\prime \prime} 0^{\prime}$, and longitude $06^{\circ} 10^{\prime \prime} 0^{\prime}$ and $07^{\circ} 10^{\prime \prime}$ 0 '.

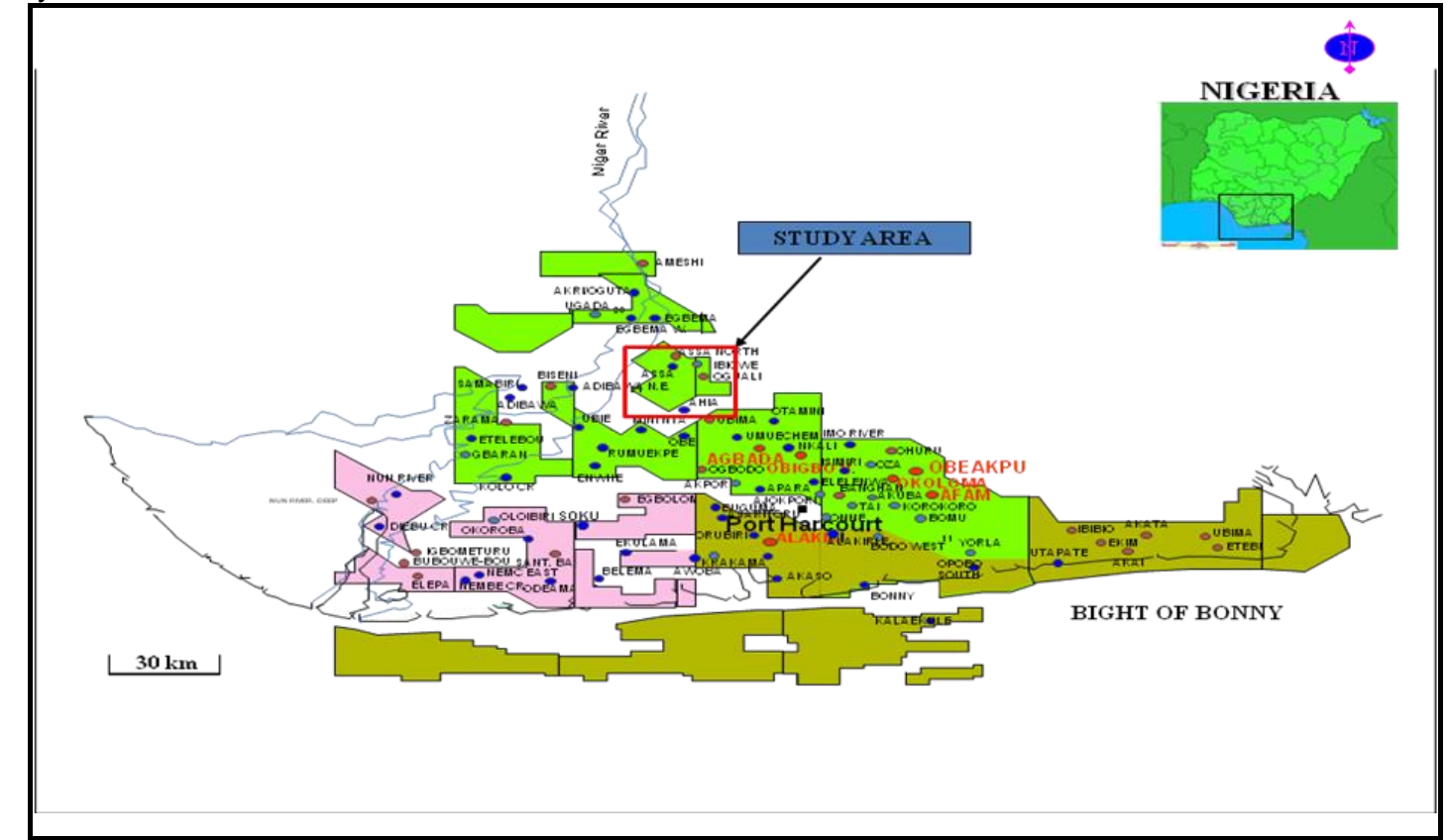

Fig. 1.0: Map Showing the Study Area (North-Central Niger Delta)

The region of low elevation within the floodplain and westward is underlain by compacted clay which is absent in the area of higher elevation, east of the escarpment. Generally, the soil formation encountered during Uphole drilling varies from clay, clayey sand and fine to coarse grained sand. There were occasional cases of gravel/pebble layer encounters in the south-eastern segment of the prospect. 
Am. J. Sci. Ind. Res., 2012, 3(5): 252-262

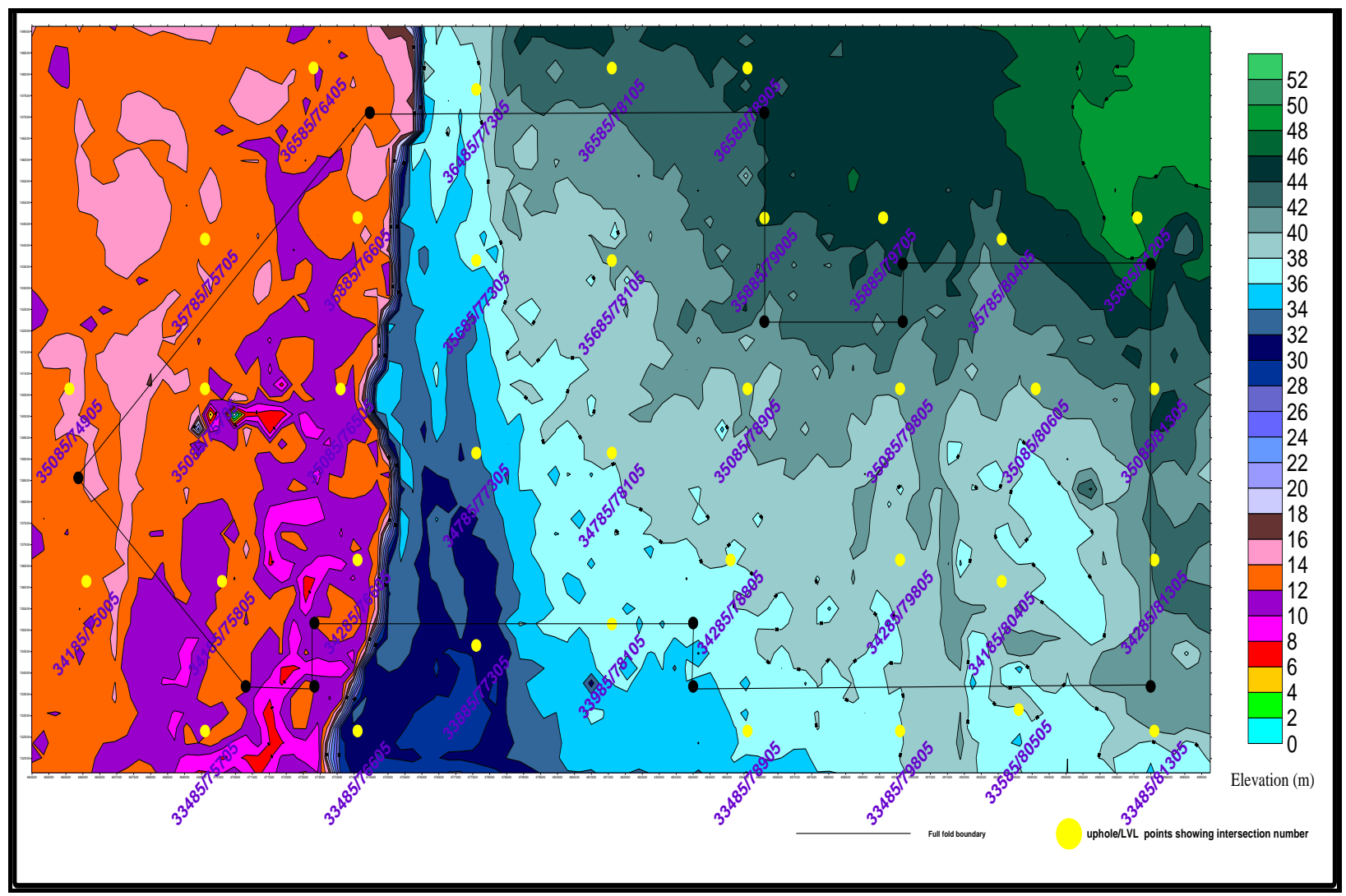

Fig. 2.0: Topographic Map of the Survey Area with Uphole/LVL points overlay

\section{Field Operations and Equipment}

An Uphole/LVL (refraction) survey in the NorthCentral onshore Niger Delta was carried out on 36 locations on a grid of $4 \times 4 . \mathrm{km}^{2}$ (figure 3.0). Uphole survey was conducted at locations where surface water existed and accessible by water truck for deep hole drilling while the surface LVL (refraction) was carried out on dry land areas where water delivery by truck was impossible. In this case, only $1.0 \mathrm{~m}$ holes were thumped to bury charges. Nineteen of the proposed 36 survey locations were shifted from the planned grid positions by a maximum of a receiver or source line to more accessible locations to deliver water; but near the originally designed grid. Where such shift will significantly distort the original grid, surface LVL refraction was shot at the planned location.

\section{Uphole (Refraction) Survey}

Each Uphole (refraction) survey location was drilled to $63.0 \mathrm{~m}$ depth. The recording hole was cased with plastic casings and logged to maximum depth of 60.0 $\mathrm{m}$. A source hole of $1.0 \mathrm{~m}$ deep was drilled $2.0 \mathrm{~m}$ away from the recording hole. Drilling was by semimanual, engine powered rotary method. This involves rotating drilling stem manually and drilling mud was pumped through to flush out cuttings. The drilling mud was formulated from drilling chemicals (bentonite and EZ mud) to provide hole stability and transportation of cuttings to surface. A downhole cable with 11 hydrophones positioned at different intervals was used (figure 4.0). 


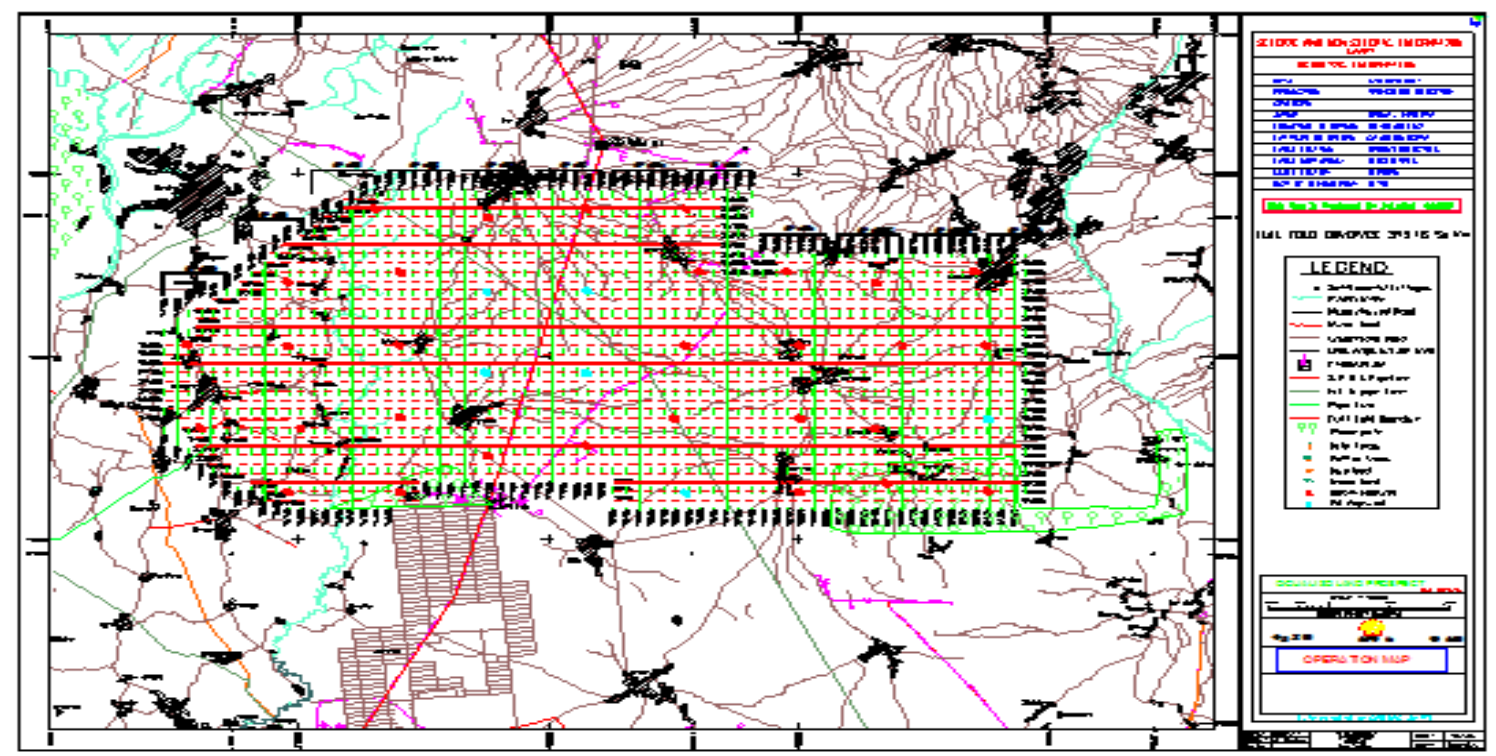

Fig 3.0: Uphole/ LVL Refraction Survey Location Map

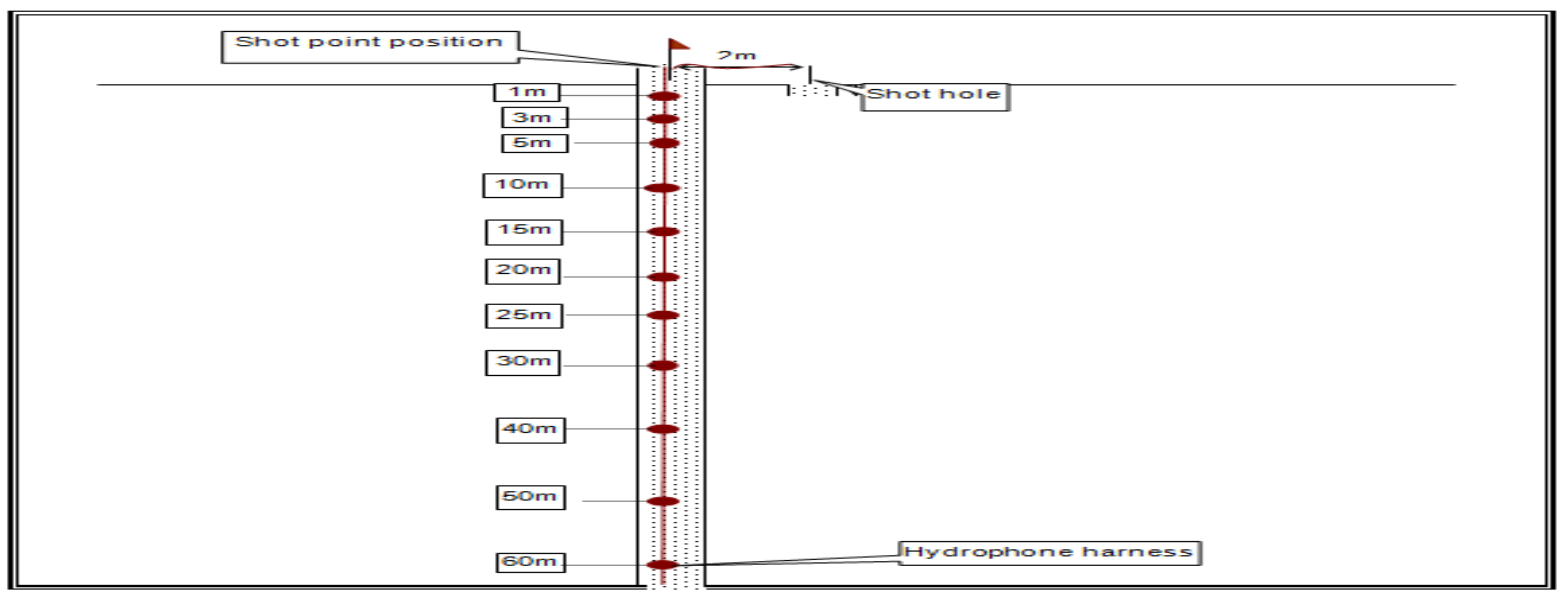

Fig. 4.0: Schematic of Uphole Survey Hydrophone/Source array Diagram Data Processing/Analysis

\section{LVL (Refraction) Recording}

LVL (Refraction) recording spread consists of 12 SM4, $10 \mathrm{~Hz}$ geophones laid on the surface but centered about the intersection as shown in Figure 5.0. Total spread length was $70.0 \mathrm{~m}$. A complete acquisition consists of 6 shots: 3 forward shots and 3 reverse shots. Shots were recorded at $75.0 \mathrm{~m}$ and $5.0 \mathrm{~m}$ off each end of the spread. In an effort to obtain deeper data, two additional shots both 210.0 $\mathrm{m}$ off each spread, were recorded. For each of the shots recorded, holes were drilled to the depth of 1.0 $\mathrm{m}$ and 5 to 10 energy caps were used. Instrumentation was by a 24 channel seismograph OYO GEOSPACE MCSeis-160MxV5.42.
The Uphole refraction survey data were processed by picking the first-breaks from the recorded traces. Time-Depth graphs (Figure 6.0) were plotted with OYO Geospace Corporation Uphole data analysis software version 1.0b. Layers thicknesses and velocities were determined by an analysis of the various graphs as follows:

i. $\quad$ Slopes were calculated by: Slope $=\frac{\Delta t}{\Delta Z}(\mathrm{~s} / \mathrm{m})$

ii. Velocities were computed

$$
V=\frac{1}{\text { slope }}=\frac{\Delta Z}{\Delta t}(\mathrm{~m} / \mathrm{s})
$$


where: $\Delta t=$ change in time, $\Delta Z=$ change in depth

iii. Thickness, $Z$ was deduced from the point of intersection of two layers to the depth axis.

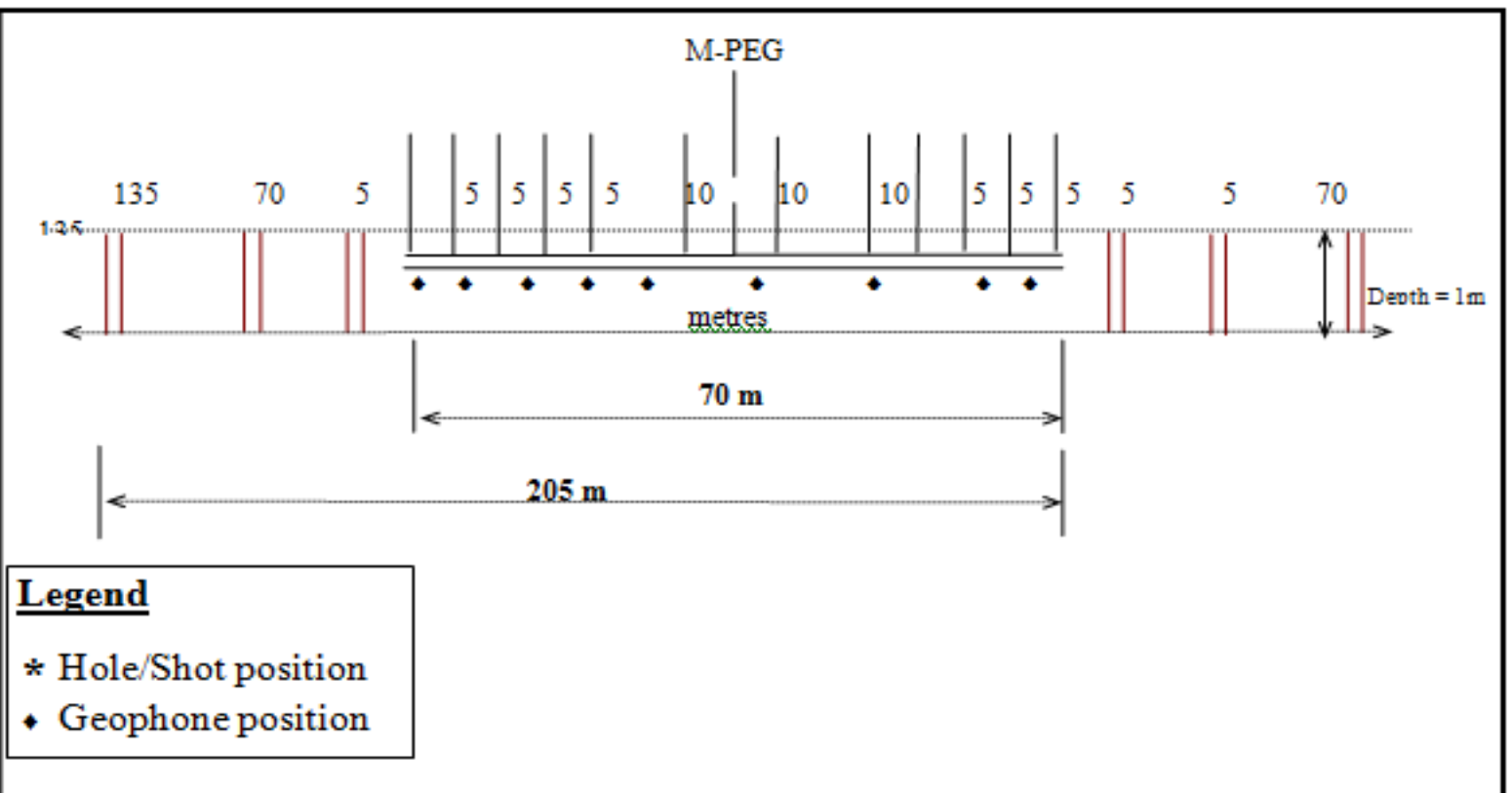

Fig 5.0: Surface LVL Refraction Survey Geophone/Source array Diagram

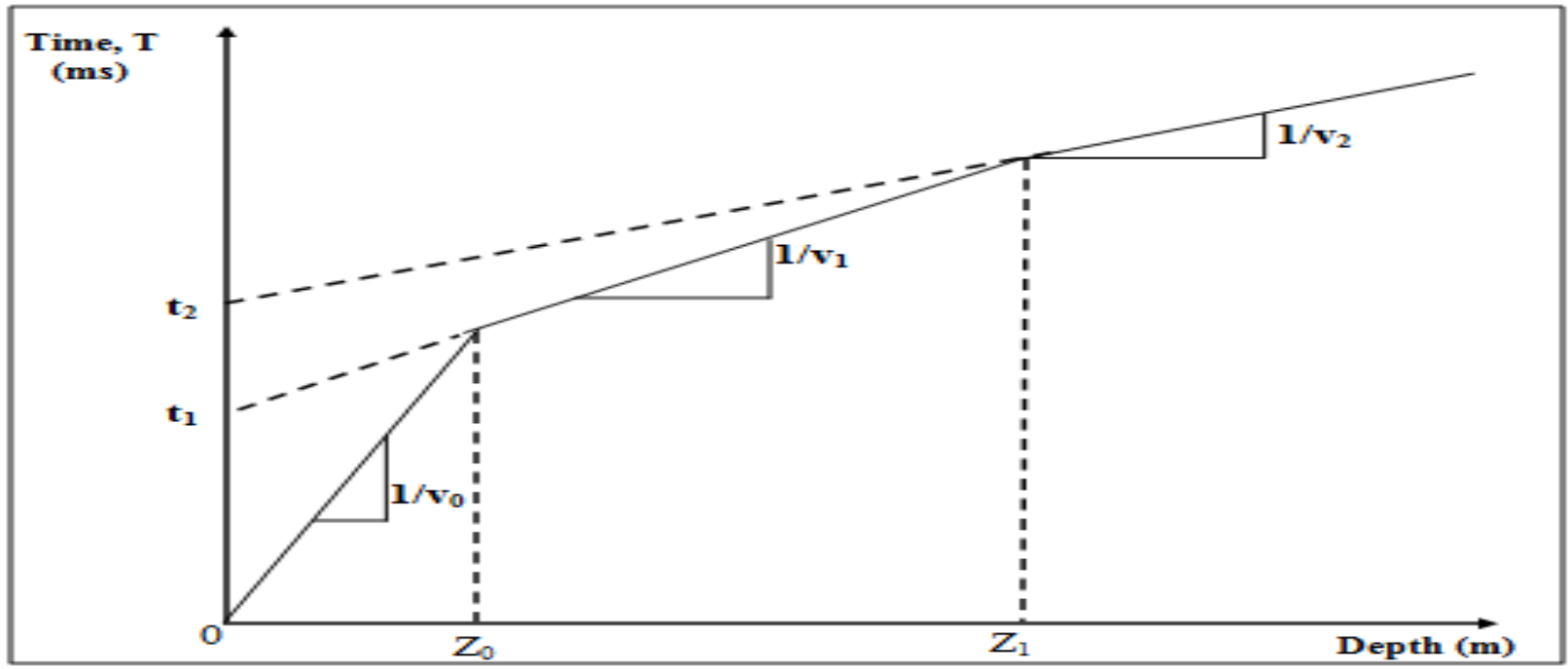

Fig 6.0: Typical Time-Depth Graph showing Uphole Refraction Profile

The surface LVL refraction data were similarly processed by picking first-breaks with OYO Geospace Corporation Uphole data analysis software version 1.0b. For each shot, a 12-trace record was produced. The weathered layer model was derived from the first-break picks and Time-Offset plots (Figure 7.0) using a package that applies advance features of Microsoft Excel. The computed values were obtained by applying the formula given by Knox (1967) and Dobrin (1976): 
Am. J. Sci. Ind. Res., 2012, 3(5): 252-262

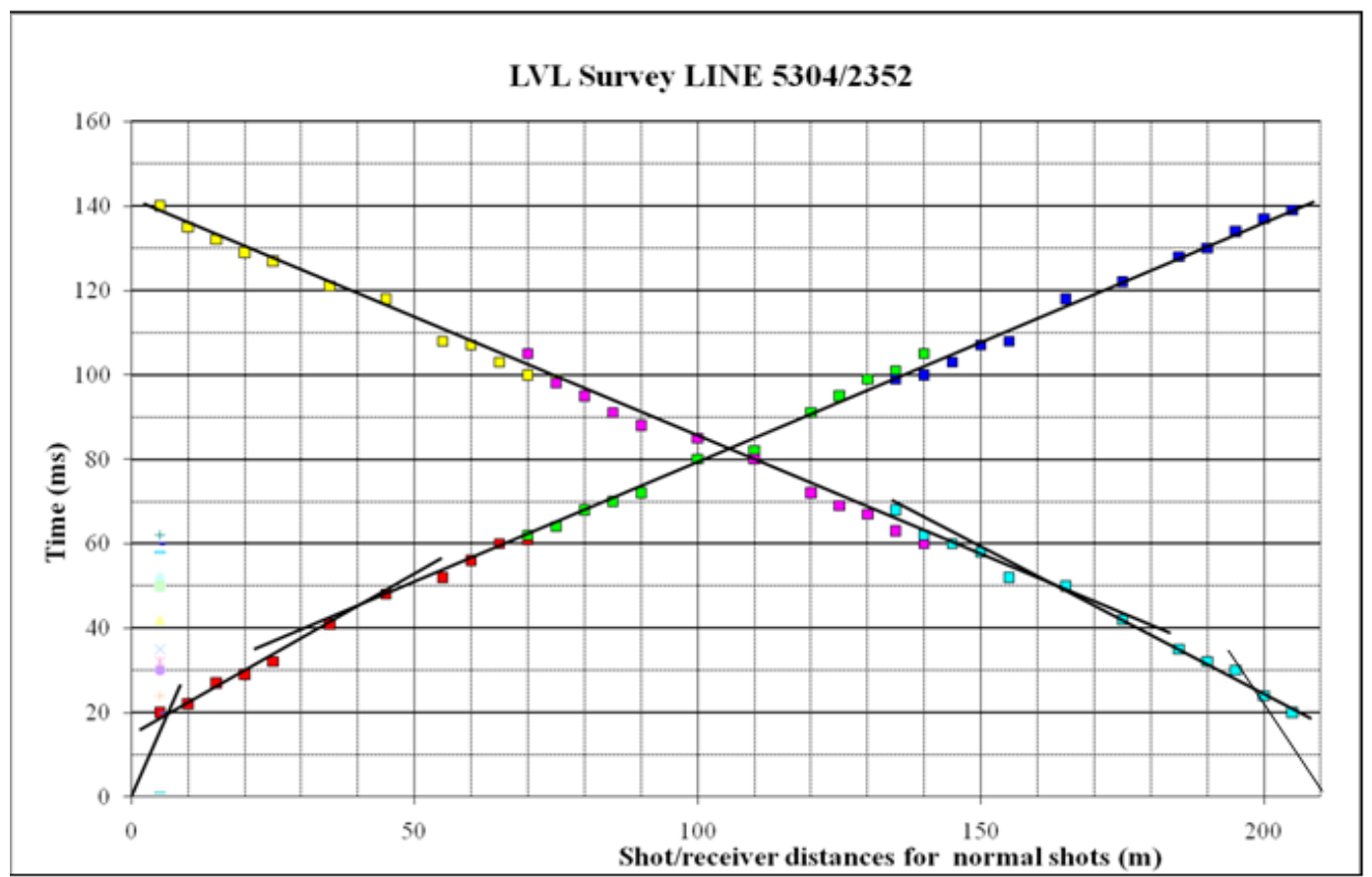

Fig 7.0: Typical Time-Distance Graph showing LVL Refraction Profile

$Z_{0}=\frac{t_{1}}{2}\left[\frac{\mathrm{V}_{1} \mathrm{~V}_{0}}{\sqrt{\left(\mathrm{V}_{1}^{2}-\mathrm{V}_{0}^{2}\right)}}\right]+\frac{D_{s}}{2}$

$Z_{1}=\left[\frac{\mathrm{t}_{2}-2 \mathrm{Z}_{0} \sqrt{\left(\mathrm{V}_{2}^{2}-\mathrm{V}_{0}^{2}\right)}}{\mathrm{V}_{2} V_{0}}\right]\left[\frac{\mathrm{V}_{2} \mathrm{~V}_{1}}{2 \sqrt{\left(\mathrm{V}_{2}^{2}-\mathrm{V}_{1}^{2}\right)}}\right]$

where: $\quad t_{1}$ and $t_{2}=$ intercept times (s) on the Distance-Time graph

$\mathrm{V}_{0}=$ velocity of the first weathering layer

$V_{1}=$ velocity of the second weathering layer

$\mathrm{V}_{2}=$ velocity of the bedrock.

$D_{s}=$ Depth of shot $(m)$

Total thickness $(\mathrm{m})$ of the weathering layer,

$\mathrm{Z}_{\mathrm{w}}=\mathrm{Z}_{0}+\mathrm{Z}_{1}$

Isopachs and Isovels were generated with Surfer 8.0 ${ }^{\mathrm{M}}$ software by the geostatistical process of kriging. Kriging technique is an exact interpolation estimator used to find the best linear unbiased estimate. Detailed discussions of kriging methods and their descriptions can be found in Goovaerts (1997). The general equation of kriging estimator is:

$Z^{*}\left(x_{p}\right)=\sum_{i=1}^{n} \lambda_{i} Z\left(x_{i}\right)$ where $Z^{*}\left(x_{p}\right)$ is the kriged value at location $x_{p}, Z\left(x_{i}\right)$ is the known value at location $x_{i}, \lambda_{i}$ is the weight associated with the data.

In this Kriging procedure, the LVL seismic refraction attribute was used as a guiding data set to grid and introduce a component of its lateral trend into the computed Uphole velocities and thicknesses.

\section{RESULTS}

Table 1.0 shows the various results of the Uphole/LVL (Refraction) surveys data analysis. The near-surface characteristics of the North-Central Niger Delta can be deduced from the geostatisticallyderived Isopach and Isovel models (Figures 8.0 to 13.0).

The overall result shows a dominant 2-layer model with 1-layer model in only five locations, mainly along the escarpment. Based on the sample density of 36 uphole/LVL points, the average thickness of the weathering layer to the first refractor consolidated layer was evaluated to be $\mathbf{1 8 . 4} \mathbf{~ m}$ with an average refractor consolidated layer velocity of $1791.40 \mathrm{~ms}^{-1}$. Weathering thicknesses ranged from 1.3 to $4.7 \mathrm{~m}$, sub-weathering thicknesses from 11.4 to $35.7 \mathrm{~m}$; weathering velocities from 119 to $941 \mathrm{~ms}^{-1}$; subweathering velocities from 425 to $1665 \mathrm{~ms}^{-1}$ and consolidated velocities from 1610 to $2208 \mathrm{~ms}^{-1}$. 


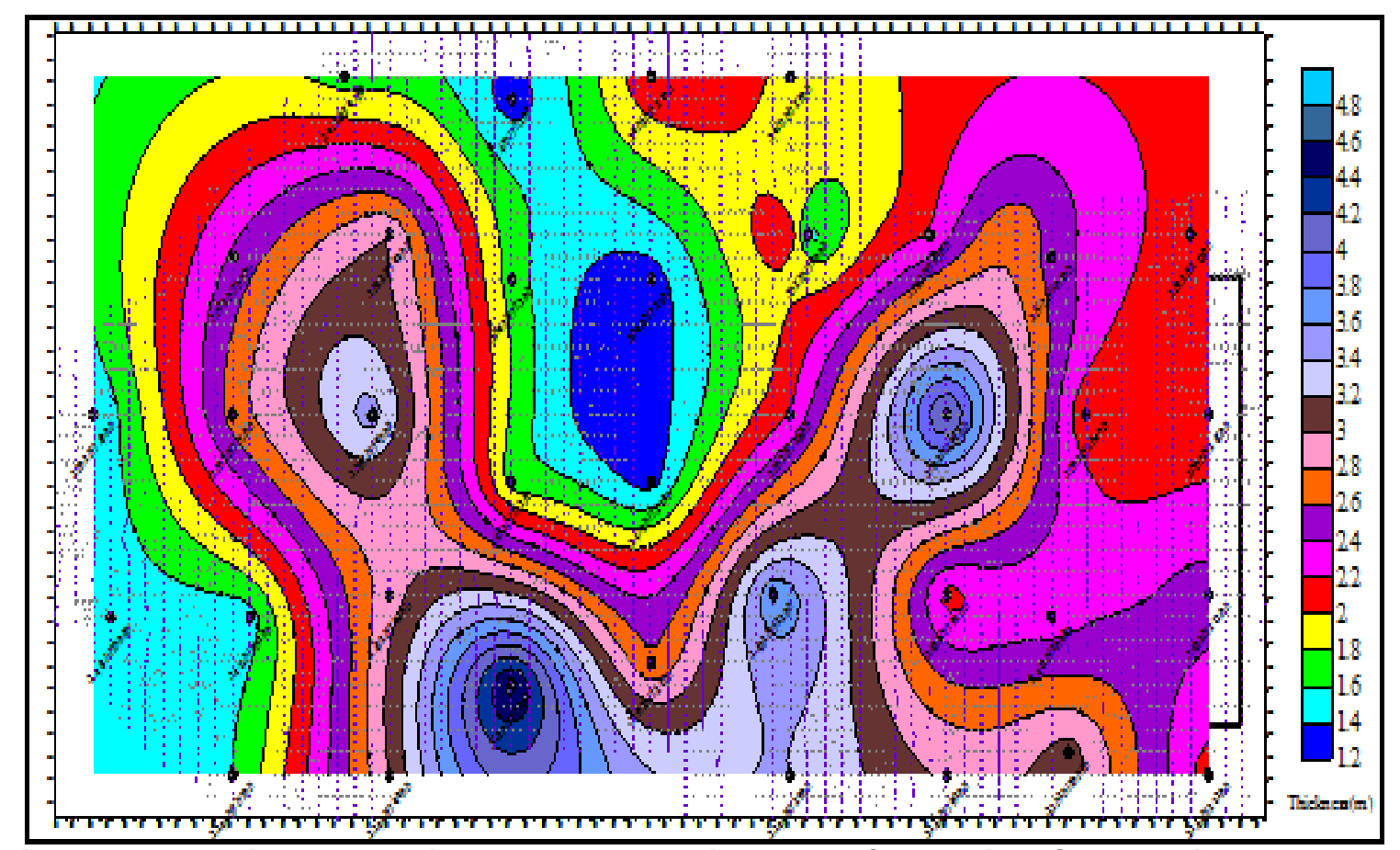

Fig 8.0: Weathering Layer thickness Isopach with Uphole/LVL Points SurveyGrid Overlay

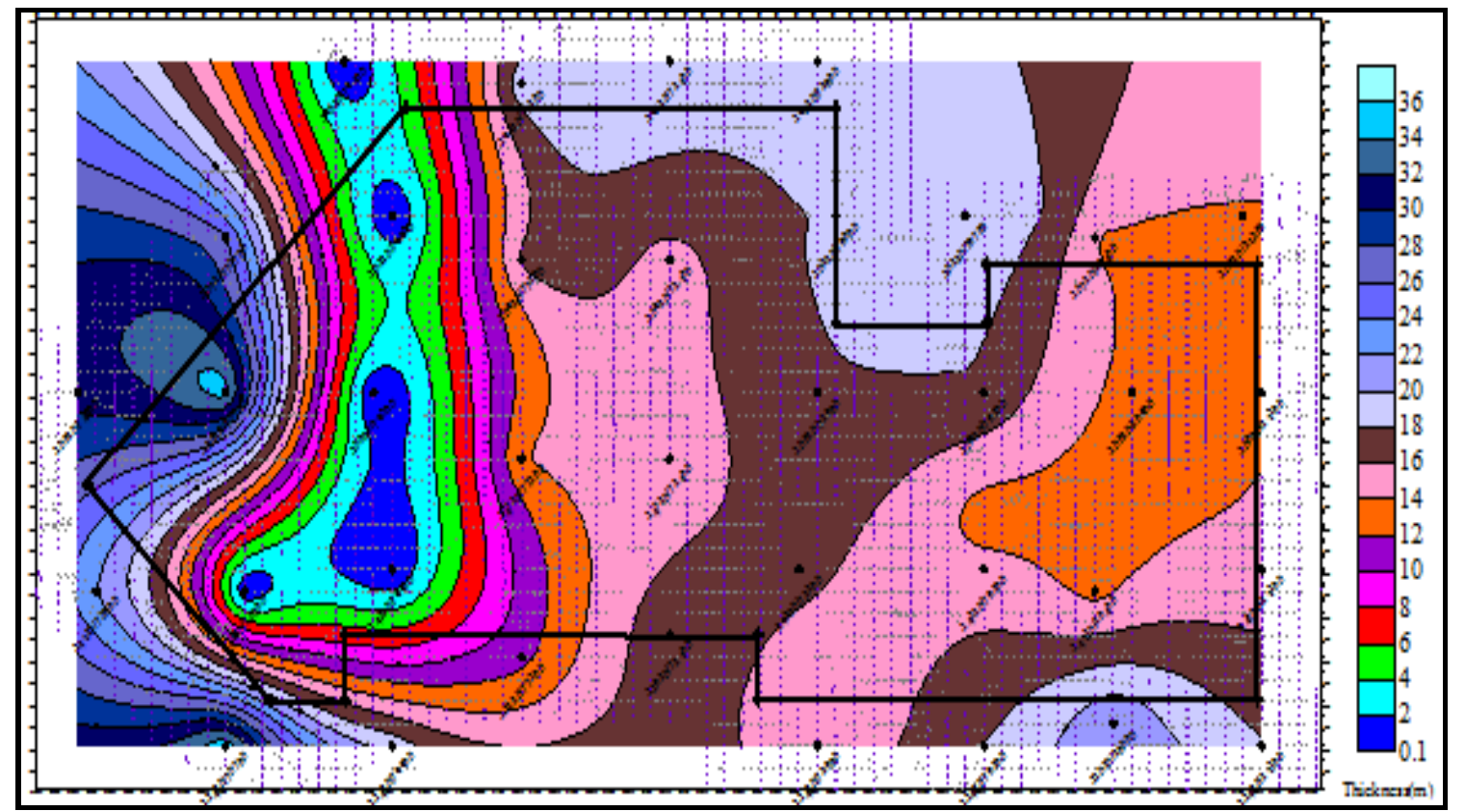

Fig 9.0: Sub-weathering Layer thickness Isopach with Uphole/LVL Points Survey Grid Overlay 


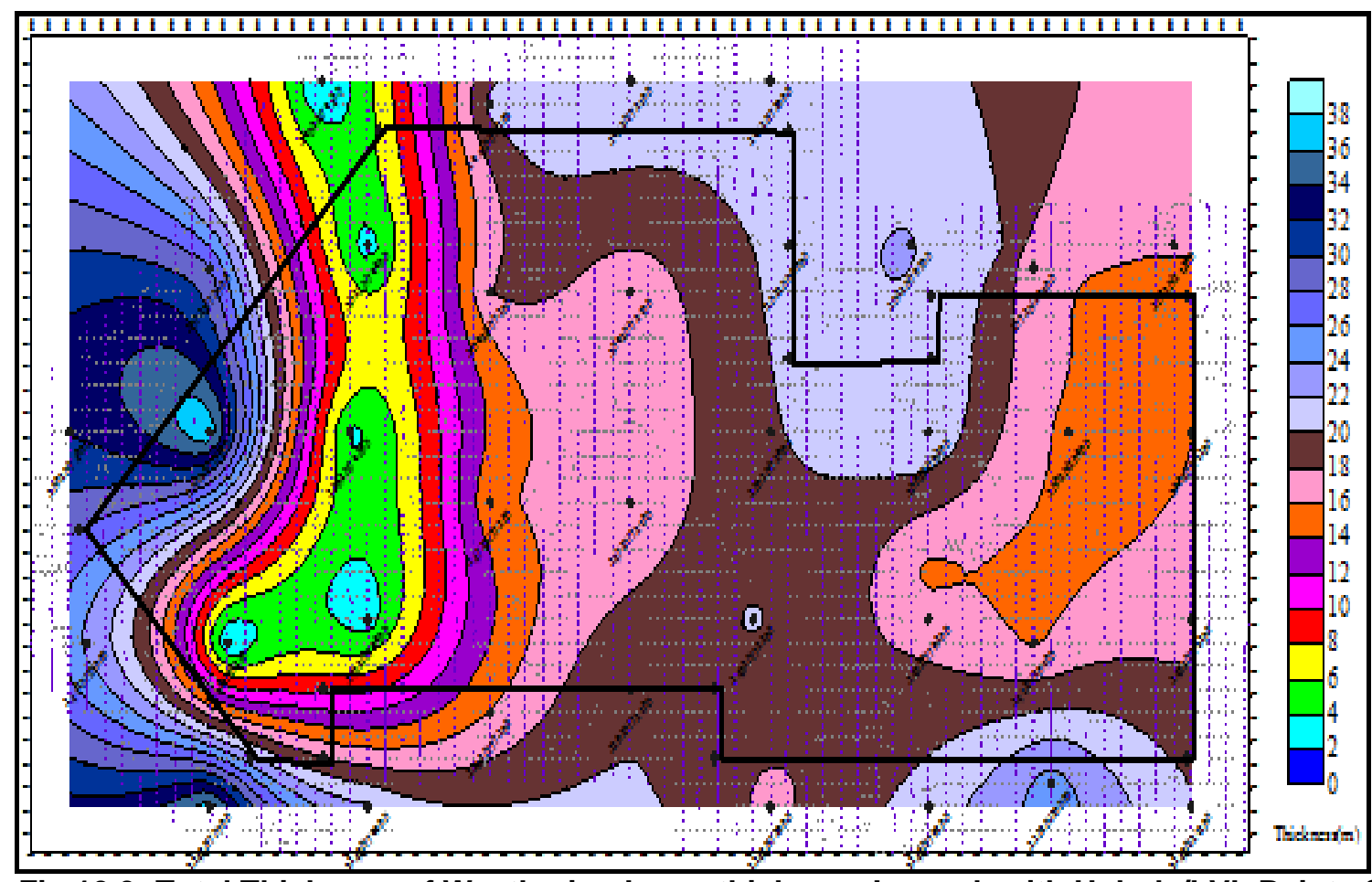

Fig 10.0: Total Thickness of Weathering Layer thickness Isopach with Uphole/LVL Points Survey Grid Overlay

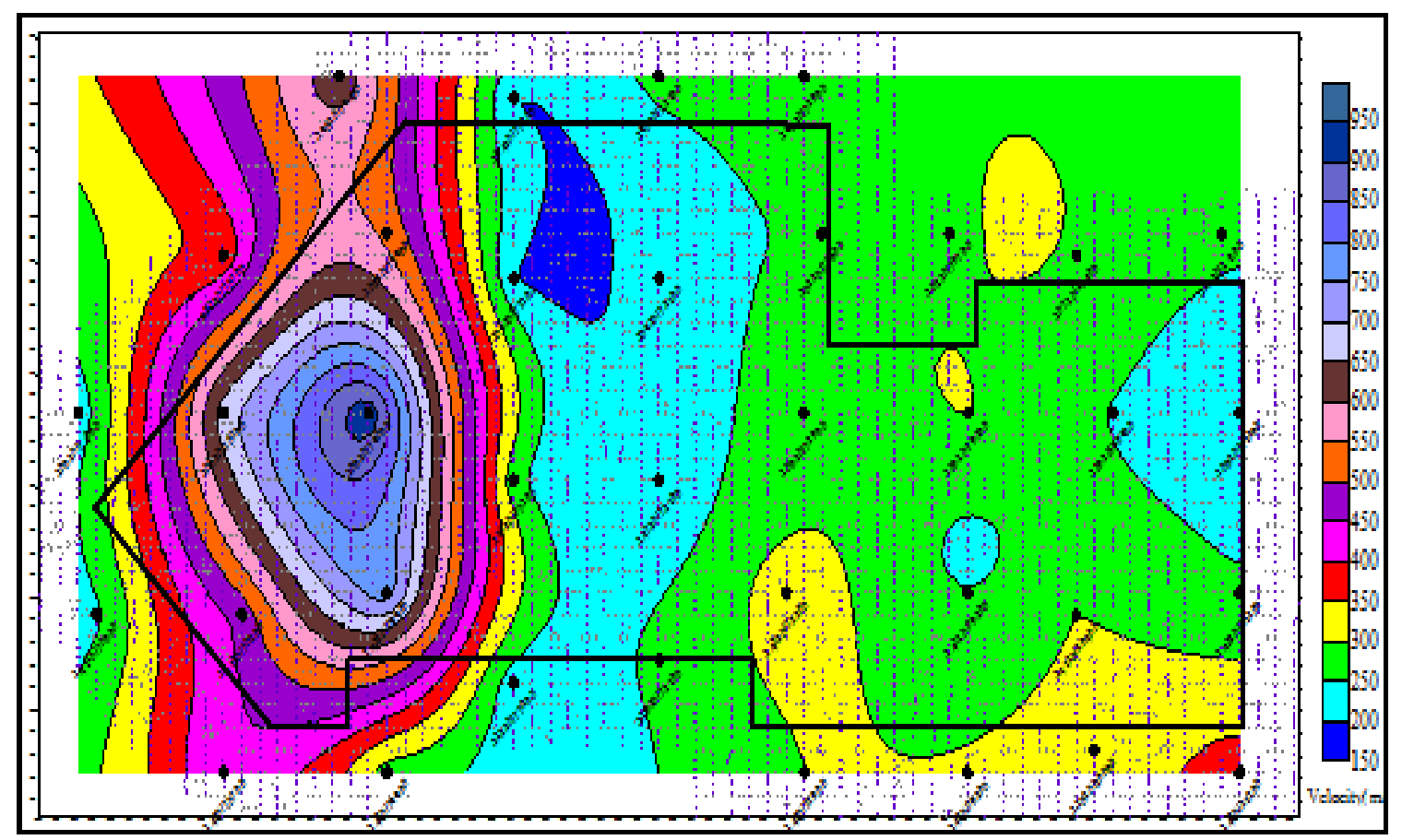

Fig 11.0: Weathering Layer Velocity Field with Uphole/LVL Points Survey Grid Overlay 


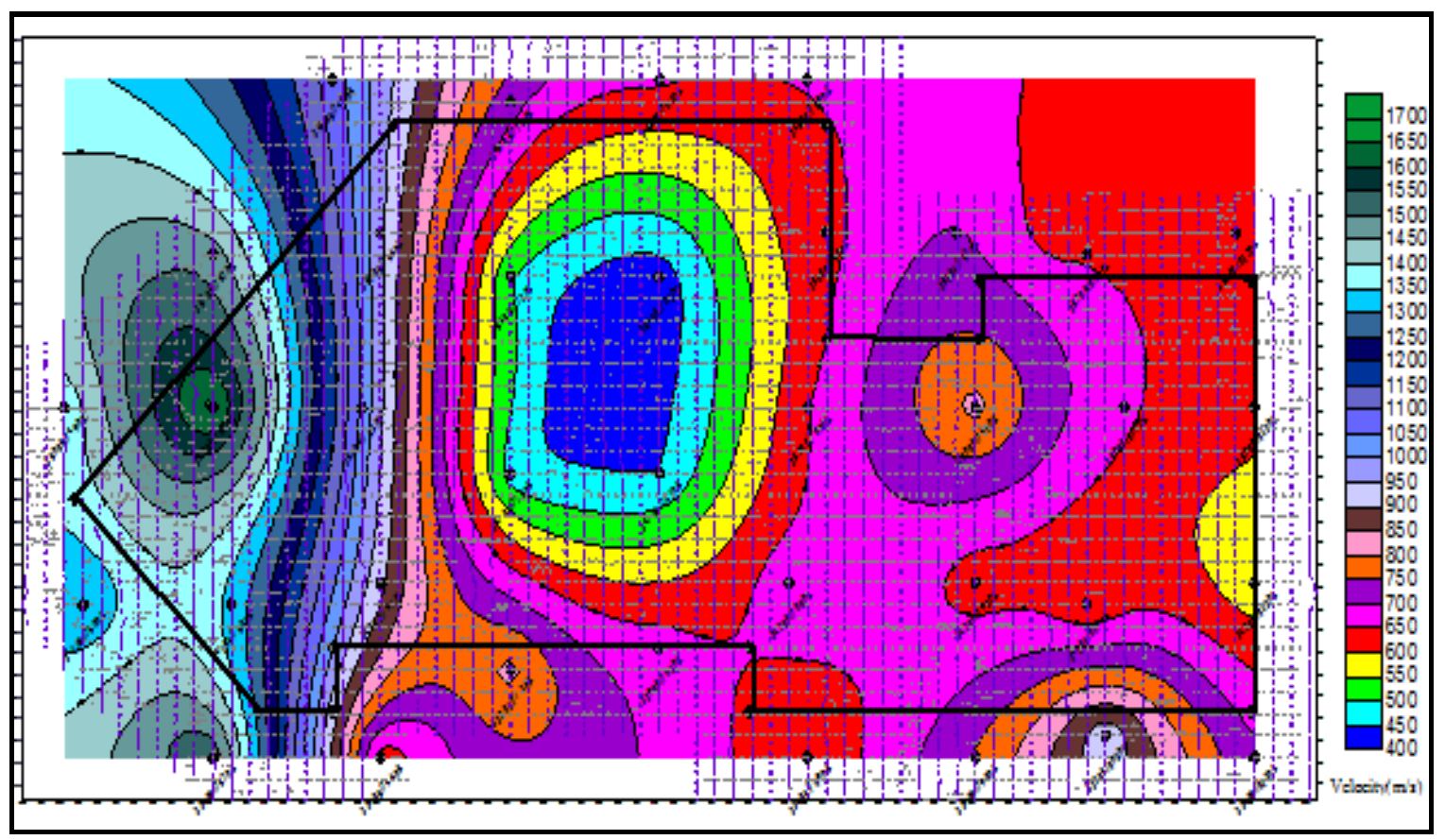

Fig 12.0: Sub-weathering Layer Velocity Field with Uphole/LVL Points Survey Grid Overlay

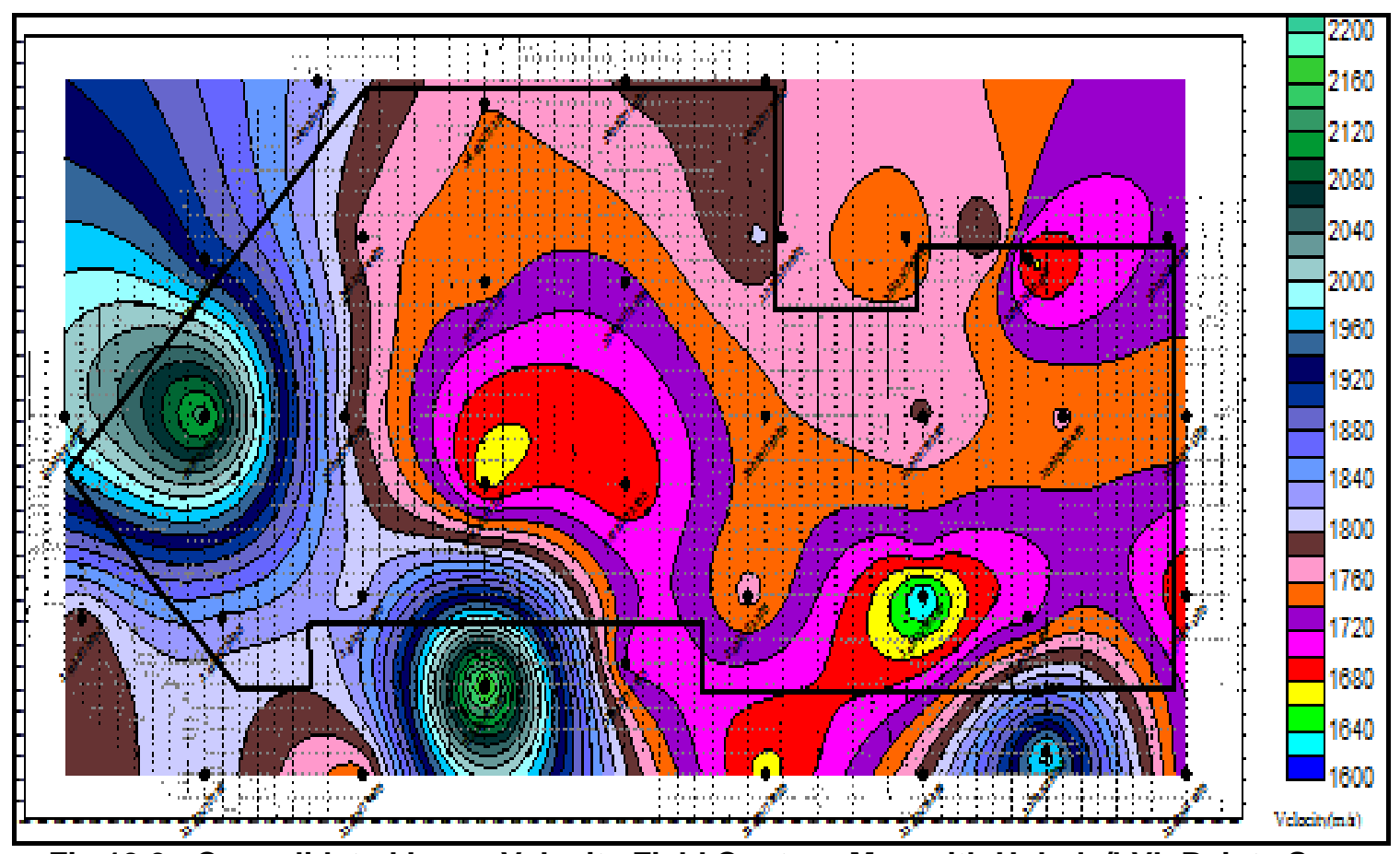

Fig 13.0: Consolidated Layer Velocity Field Contour Map with Uphole/LVL Points Survey Grid Overlay 
Am. J. Sci. Ind. Res., 2012, 3(5): 252-262

Table 1.0: Summary of Uphole/LVL (Refraction) Survey Results

\begin{tabular}{|c|c|c|c|c|c|c|c|c|c|c|}
\hline $\mathbf{S} / \mathbf{N}$ & $\begin{array}{l}\text { SHOT } \\
\text { POINT } \\
\end{array}$ & EASTINGS & NORTHINGS & $\begin{array}{c}\text { ELEV. } \\
(\mathrm{m})\end{array}$ & $\begin{array}{c}Z_{0} \\
(m)\end{array}$ & $\begin{array}{c}Z_{1} \\
(m)\end{array}$ & $\begin{array}{c}V_{0} \\
(\mathrm{~m} / \mathrm{s})\end{array}$ & $\begin{array}{c}V_{1} \\
(\mathrm{~m} / \mathrm{s})\end{array}$ & $\begin{array}{c}V_{c} \\
(\mathrm{~m} / \mathrm{s})\end{array}$ & REMARKS \\
\hline 1 & $35085 / 74905$ & 465603.34 & 140644.11 & 14.69 & 1.4 & 30.7 & 219 & 1364 & 2005 & Uphole \\
\hline 2 & $34185 / 75005$ & 466103.91 & 136143.26 & 13.32 & 1.5 & 22.0 & 240 & 1298 & 1786 & Uphole \\
\hline 3 & 33485 / 75705 & 469603.50 & 132643.26 & 11.32 & 1.6 & 35.7 & 447 & 1541 & 1817 & Uphole \\
\hline 4 & 35085 / 75705 & 469602.73 & 140644.63 & 11.24 & 2.7 & 35.3 & 678 & 1665 & 2140 & Uphole \\
\hline 5 & 34185 / 75805 & 470103.72 & 136144.20 & 11.48 & 1.5 & - & 466 & - & 1835 & Uphole \\
\hline 6 & 35785 / 75705 & 469604.12 & 144144.42 & 13.80 & 2.0 & 26.3 & 358 & 1475 & 1916 & Uphole \\
\hline 7 & $36585 / 76405$ & 472803.12 & 148147.33 & 12.02 & 1.7 & - & 639 & - & 1828 & Uphole \\
\hline 8 & 35085 / 76505 & 473602.77 & 140639.76 & 12.26 & 3.5 & - & 941 & - & 1800 & Uphole \\
\hline 9 & 35885 / 76605 & 474104.41 & 144646.86 & 14.12 & 3.0 & - & 537 & - & 1772 & Uphole \\
\hline 10 & 33485 / 76605 & 474103.21 & 132643.54 & 31.79 & 3.0 & 19.30 & 276 & 621 & 1747 & Uphole \\
\hline 11 & 34285 / 76605 & 474102.01 & 136643.23 & 12.10 & 2.9 & - & 778 & - & 1815 & Uphole \\
\hline 12 & 33885 / 77305 & 477603.68 & 134644.28 & 30.87 & 4.7 & 11.4 & 218 & 817 & 2208 & Uphole \\
\hline 13 & 35685 / 77305 & 477604.05 & 143645.66 & 36.74 & 1.7 & 16.4 & 200 & 503 & 1750 & LVL \\
\hline 14 & 36485 / 77305 & 477603.78 & 147643.06 & 36.55 & 1.3 & 19.4 & 199 & 722 & 1760 & Uphole \\
\hline 15 & 34785 / 77305 & 477603.94 & 139143.04 & 33.10 & 1.7 & 13.9 & 264 & 475 & 1667 & LVL \\
\hline 16 & 33985 / 78105 & 481605.39 & 135143.55 & 36.52 & 2.6 & 17.4 & 265 & 673 & 1712 & Uphole \\
\hline 17 & 35685 / 78105 & 481603.51 & 143643.56 & 40.20 & 1.3 & 15.3 & 225 & 425 & 1735 & LVL \\
\hline 18 & 34785 / 78105 & 481603.57 & 139143.80 & 38.60 & 1.3 & 14.9 & 205 & 450 & 1680 & LVL \\
\hline 19 & 36585 / 78105 & 481603.59 & 148143.43 & 42.77 & 2.2 & 19.0 & 265 & 658 & 1783 & Uphole \\
\hline 20 & 36585 / 78905 & 485604.13 & 148143.94 & 44.45 & 2.2 & 18.1 & 256 & 635 & 1807 & Uphole \\
\hline 21 & 35885 / 79005 & 486103.30 & 144637.50 & 44.50 & 1.5 & 19.5 & 290.0 & 634.0 & 1767.0 & Uphole \\
\hline 22 & 34285 / 78805 & 485104.00 & 136642.90 & 37.90 & 3.8 & 16.4 & 324 & 681 & 1770 & Uphole \\
\hline 23 & 34285 / 79805 & 490104.16 & 136643.96 & 39.93 & 2.1 & 15.2 & 252 & 630 & 1610 & Uphole \\
\hline 24 & 33485 / 79805 & 490102.97 & 132643.74 & 37.60 & 2.6 & 12.8 & 233 & 659 & 1721 & Uphole \\
\hline 25 & 35085 / 78905 & 485604.20 & 140643.00 & 40.50 & 2.2 & 17.6 & 290 & 649 & 1756 & Uphole \\
\hline 26 & 33485 / 78905 & 485603.00 & 132643.60 & 36.10 & 3.4 & 14.0 & 300 & 603 & 1670 & LVL \\
\hline 27 & 35885 / 79705 & 489604.53 & 144643.44 & 44.39 & 2.2 & 19.9 & 291 & 704 & 1742 & Uphole \\
\hline 28 & 35085 / 79805 & 490103.55 & 140643.81 & 40.84 & 4.3 & 17.7 & 302 & 816 & 1784 & Uphole \\
\hline 29 & 35785 / 80405 & 493103.63 & 144143.14 & 44.07 & 2.5 & 13.9 & 286 & 646 & 1670 & Uphole \\
\hline 30 & 35085 / 81305 & 497604.23 & 140643.99 & 43.60 & 2.1 & 13.9 & 224 & 616 & 1759 & Uphole \\
\hline 31 & 35885 / 81205 & 497103.61 & 144643.87 & 47.44 & 2.8 & 17.6 & 313 & 630 & 1803 & Uphole \\
\hline 32 & 33585 / 80505 & 493603.60 & 133143.60 & 37.50 & 3.1 & 21.9 & 322 & 939 & 1998 & Uphole \\
\hline 33 & 33485 / 81305 & 497603.95 & 132643.40 & 39.50 & 2.1 & 18.1 & 374 & 710 & 1721 & Uphole \\
\hline 34 & 34285 / 81305 & 497603.89 & 136641.49 & 42.40 & 2.5 & 14.7 & 255 & 565 & 1680 & LVL \\
\hline 35 & 35085 / 80605 & 494103.42 & 140643.65 & 41.09 & 2.0 & 13.5 & 248 & 660 & 1764 & Uphole \\
\hline 36 & 34185 / 80405 & 493102.50 & 136142.56 & 39.26 & 2.3 & 13.4 & 301 & 607 & 1712 & Uphole \\
\hline
\end{tabular}


Table 2.0: Summary of Interpretations of Isopach and Isovel Models

\begin{tabular}{|c|c|c|c|c|}
\hline \multirow[t]{2}{*}{ Geological property } & \multicolumn{2}{|c|}{ Thickness (m) } & \multicolumn{2}{|c|}{ Velocity $\left(\mathrm{ms}^{-1}\right)$} \\
\hline & Zone of High & Zone of Low & Zone of High & Zone of Low \\
\hline Weathering Layer & Southern part & North-Central part & West-Central portion & $\begin{array}{l}\text { Central portion } \\
\text { stretching from North } \\
\text { to South }\end{array}$ \\
\hline $\begin{array}{l}\text { Sub-weathering } \\
\text { Layer }\end{array}$ & Extreme West & $\begin{array}{l}\text { West-Central } \\
\text { stretching from North } \\
\text { to South }\end{array}$ & Western portion & Central portion \\
\hline Consolidated Layer & & & $\begin{array}{l}\text { Extreme West and } \\
\text { Southern portions }\end{array}$ & $\begin{array}{l}\text { South-Eastern } \\
\text { portion }\end{array}$ \\
\hline
\end{tabular}

Table 2.0 is a summary of the interpretations of the Isopach and Isovel models obtained for the nearsurface. These show the various ranges of thicknesses and velocities of the different near-surface layers and their positions of high and low within the prospect.

CONCLUSION AND RECOMMENDATION: The average thickness suggests that, where possible, shots should be located at depths of about $\mathbf{1 9 . 0} \mathrm{m}$ below the weathering layer where signals travel at velocities devoid of time delays during 3D/4D seismic surveys in this area. This has the advantage of by-passing and consequently minimizing the spurious effects of the low velocity weathered layer during acquisition and initial processing of field data in which static and dynamic corrections are applied.

The presence of extensive compacted clay materials observed within the area of low elevation of the Sambreiro flood plain accounts for the relatively high velocities profile in the extreme west of the survey area. The low weathering thicknesses observed within the vicinity of the Sambreiro River in the Central portions of the north-west through the south-west indicates the presence of loose unconsolidated and aerated soil materials which may lead to high absorption of seismic energy. This general variation in the thickness of the weathering layer may, if not corrected for, may lead to false indications of significant structural features.

Although, Isopach and Isovel models have been generated to provide a description of the near-surface trend, the volume of data control points is still insufficient for a conclusive analysis. Future research should ensure that at least 60 data control points (Uphole and LVL Refraction data) are geostatistically integrated to draw a conclusion on the near-surface structural properties.

\section{ACKNOWLEDGEMENT}

The authors are grateful to the Geosolutions Department of Shell Petroleum Development Company (SPDC), Nigeria Limited under whose auspices this research was conducted. We are particularly thankful to
CNPC/BGP for granting us the opportunity to have access to the data and software used for this study. We also thank the Department of Petroleum Resources for the approvals to release the data

\section{REFERENCES}

Dobrin, M. B. (1983). Introduction to Geophysical Prospecting. Mc Graw-Hill Book Co., London.3 ${ }^{\text {rd }}$ Ed., Pp. 294 - 300; $307-310$.

Enikanselu, P. A. (2008). Geophysical Seismic Refraction and Uphole Survey Analysis of Weathered Layer Characteristics in the "Mono" Field, South-Western Niger Delta, Nigeria. Pacific Journal of Science and Technology. 9 (2) 537-546

Eze, C. L., Okwueze, E. E. and Uko, E. D. (2003). The velocity - thickness characteristics of the mangrove swamp low velocity layer (LVL) South central Niger Delta, Nigeria. Global Journal of pure and applied sciences, Vol. 9, No. 3, p. 369-374.

Goovaerts, P. (1997). Geostatistics for Natural Resources Evaluation. Oxford University Press, New York. pp.483

Knox, W. A., (1967), Multi-layer near surface reflection Computation in Musgrave, A.W. Ed; Seismic reflection prospecting: Soc. of Expl. Geophysics $197-216$.

Marsden, D., (1993) Static correction. A review, The Leading Edge.

Osagie, L. O. (2009). Weathering Structure of SouthWestern Niger Delta, Nigeria. Pacific Journal of Science and Technology. 10 (2) 672-679

Singh, K. P. and Kumar B. (2006). Can Shallow Refraction Survey Replace Uphole Survey? Conference Paper, 6th International Conference \& Exposition on Petroleum Geophysics, "Kolkata 2006", 180-183.

Telford, W. M., Geldart, L. P., Sheriff, P. E. and Keys, D. A. (1976). Applied Geophysics. Cambridge University Press, London, Pp. $271-274 ; 281-284$

Uko, E. D., Ekine, A. S., Ebeniro, J. O. and Ofoegbu, C. O. (1992). Weathering Structure of the East Central Niger Delta, Nigeria, Geophysics 57 (9): 1228-1233. 